\title{
Prevention Urea Toxicity on Water Content of Muscles of a Freshwater Field Crab, Barytelphusa guerini by using an Additive, Methionine
}

\author{
A. N. Kulkarni ${ }^{1}$, B. D. Waghmare ${ }^{2}$ \\ Department of Fishery Science, N.E.S. Science College, Nanded (M.S.) 431605, India
}

\begin{abstract}
The study of prevention of urea toxicity on a fresh water field crab, Barytelphusa guerini is most important aspect of this study. Fresh water field crab, B. Guerini collected from river Godavari at Nanded, and brought to the laboratory for acclimatization. After acclimatization they were exposed to various concentration of urea ranging from 5 to $40 \mathrm{~g} / \mathrm{L}$ estimate LC50 value for 96 hr. After estimation of LC50 value $(25 \mathrm{gm} / \mathrm{L})$ they were exposed to sublethal concentration of urea $(10 \mathrm{gm} / \mathrm{L})$ to study the effect on Water content. It was observed that Water content was loss in urea treated crab; whereas Methionine treated crab shows increased in water content.
\end{abstract}

Keyword: Crab, Urea, Methionine, Water Content

\section{Introduction}

Water pollution is increasing day by day by different pollutants like heavy metals, pesticides, fertilizers etc. These pollutants directly or indirectly enter in the body of aquatic animals and disturb biochemical and physiological patterns of animals. Urea which is used as a fertilizers and protein supplement for ruminant's animals enters in aquatic system from various ways. It effects on flora and fauna. Urea ulter the biochemical and physiological pattern at cellular level of aquatic animals including crab. Urea destabilizes the Water content of the muscles and can be prevented by using additives. The present work was undertaken to study the toxic effect of urea on Water content of aquatic animals and prevention of toxicity by using additives. This will provide the scientific information for aqua culturists to minimize the effect by using sulphur containing amino acid Methionine as an additive so that food value of crab remains in good condition.

\section{Materials and Methods}

Fresh water crab field crab, B. guerini collected from river Godavari near Nanded, and brought to laboratory for acclimatization and kept in an aerated container the plastic pools for 8 to 10 days. A layer of sand 4 to 5 inches was spreads over bottom and water was added in it, during this period they were fed with dry prawn powder. Uneaten food and dead animals they were removed. After 8 days animals they were exposed to various concentration of urea ranging from 5 to $40 \mathrm{~g} / \mathrm{L}$ to estimate $\mathrm{LC}_{50}$ value for $96 \mathrm{hr}$ in. Medium of the container was maintained by changing the old water and adding new fresh water after every $24 \mathrm{hr}$ exposure by using graphical method of Litchfield and Willcoxon (1949) and it was $25 \mathrm{gm} / \mathrm{L}$. Then animals were exposed to 3 different sets for $96 \mathrm{hr}$. first set was control (without urea) and second set was sub lethal concentration of urea $(10 \mathrm{mg} / \mathrm{L})$ and third with urea and additive Methionine $(1 \mathrm{mg} / \mathrm{L})$. After $24 \mathrm{hrs}$ and $96 \mathrm{hr}$ of exposure period, animals were sacrificed to estimate Water content from muscles. It was estimate by drying the tissues in oven at $100^{\circ} \mathrm{C}$ for $24 \mathrm{hr}$.

\section{Results and Discussion}

Table No. 1 shows the effect of urea on Water content of crab after exposure to 24 and 96 hour. It was decreased in 24 and 96 hours when compared to control. Water content was less in experimental set where animals were treated with urea along with a additive, Methionine. Urea, the fertilizers used in agriculture and aquaculture to increase the production. Low concentration of urea in aquatic environments is also considered as a growth promoter. Whereas higher concentration of urea pollutes the environment and it affects on water content. An additive Methionine prevents toxicity of urea by inhibition at cellular level. Shmidl-Nielsen (1977) observed no change in water in the tissue of Winter Flounders when exposed to Methyl mercury. Verma et.al. (1983) reported that decreasing water content in tissue of Thiotox and Malathion treated fish Notopterus nontopterus.

Table 1: Shows, Water content in chelate leg muscles of urea treated and urea+ additives treated crab, Barytelphusa guerini and values are expressed in $\mathrm{mg} / \mathrm{gm}$ in tissues

\begin{tabular}{|c|c|c|c|c|c|}
\hline \multirow{2}{*}{ Sr. No. } & Concentration & \multicolumn{2}{|c|}{$\begin{array}{c}24 \text { hours exposure } \\
\text { period }\end{array}$} & \multicolumn{2}{|c|}{$\begin{array}{c}\text { hour exposure } \\
\text { period }\end{array}$} \\
\cline { 3 - 6 } & & Male & Female & Male & Female \\
\hline 1 & Control & 0.39 & 0.34 & 0.32 & 0.29 \\
\hline 2 & Urea $10 \mathrm{gm} / \mathrm{L}$ & 0.49 & 0.51 & 0.45 & 0.41 \\
\hline 3 & $\begin{array}{c}\text { Urea } 10 \mathrm{gm} / \mathrm{L}+ \\
\text { additive } 1 \mathrm{mg} / \mathrm{L}\end{array}$ & 0.56 & 0.58 & 0.59 & 0.45 \\
\hline
\end{tabular}

\section{Acknowledgements}

Dr. A. N. Kulkarni is thankful to SRTMU, Nanded for providing financial assistance in the form of MRP. Dr. B. D. Waghmare is thankful to UGC for providing financial assistance through MANF.

\section{References}

[1] Schmidt-Nielsen, B. (1977): Effect of Methyl Mercury upon Osmoregulation, cellular volume and iron regulation in winter Flounder, Pseudopleuronectes 


\section{International Journal of Science and Research (IJSR) \\ ISSN (Online): 2319-7064}

Index Copernicus Value (2013): 6.14 | Impact Factor (2014): 5.611

americanus, in response to marine biota to pollutants.

Academic press Inc. New York.

[2] Verma, S.R., Tonk, I.P. and Virendra kumar (1983):

Effect of Thiotox Malathion and their two combinations

on tissues of Notopterus notopterus. Journal of Environmental Biology 4(1): 27-33. 